\title{
Lanosterol biosynthesis pathway (version 2019.4) in the IUPHAR/BPS Guide to Pharmacology Database
}

\author{
Helen E. Benson ${ }^{1}$
}

1. University of Edinburgh, UK

\begin{abstract}
Lanosterol is a precursor for cholesterol, which is synthesized primarily in the liver in a pathway often described as the mevalonate or HMG-CoA reductase pathway. The first two steps (formation of acetoacetyl CoA and the mitochondrial generation of (S)-3-hydroxy-3-methylglutaryl-CoA) are also associated with oxidation of fatty acids.
\end{abstract}

\section{Contents}

This is a citation summary for Lanosterol biosynthesis pathway in the Guide to Pharmacology database (GtoPdb). It exists purely as an adjunct to the database to facilitate the recognition of citations to and from the database by citation analyzers. Readers will almost certainly want to visit the relevant sections of the database which are given here under database links.

GtoPdb is an expert-driven guide to pharmacological targets and the substances that act on them. GtoPdb is a reference work which is most usefully represented as an on-line database. As in any publication this work should be appropriately cited, and the papers it cites should also be recognized. This document provides a citation for the relevant parts of the database, and also provides a reference list for the research cited by those parts.

Please note that the database version for the citations given in GtoPdb are to the most recent preceding version in which the family or its subfamilies and targets were substantially changed. The links below are to the current version. If you need to consult the cited version, rather than the most recent version, please contact the GtoPdb curators.

\section{Database links}

Lanosterol biosynthesis pathway

http://www.guidetopharmacology.org/GRAC/FamilyDisplayForward?familyld=104

Introduction to Lanosterol biosynthesis pathway

http://www.guidetopharmacology.org/GRAC/FamilyIntroductionForward?familyld=104

Enzymes

acetyl-CoA acetyltransferase 1

http://www.guidetopharmacology.org/GRAC/ObjectDisplayForward?objectld=2435

acetyl-CoA acetyltransferase 2

http://www.guidetopharmacology.org/GRAC/ObjectDisplayForward?objectld=2436 
hydroxymethylglutaryl-CoA synthase 1

http://www.guidetopharmacology.org/GRAC/ObjectDisplayForward?objectld=638

hydroxymethylglutaryl-CoA synthase 2

http://www.guidetopharmacology.org/GRAC/ObjectDisplayForward?objectld=2432

hydroxymethylglutaryl-CoA reductase

http://www.guidetopharmacology.org/GRAC/ObjectDisplayForward?objectld=639

mevalonate kinase

http://www.guidetopharmacology.org/GRAC/ObjectDisplayForward?objectld=640

phosphomevalonate kinase

http://www.guidetopharmacology.org/GRAC/ObjectDisplayForward?objectld=641

diphosphomevalonate decarboxylase

http://www.guidetopharmacology.org/GRAC/ObjectDisplayForward?objectld=642

isopentenyl-diphosphate $\triangle$-isomerase 1

http://www.guidetopharmacology.org/GRAC/ObjectDisplayForward?objectld=646

isopentenyl-diphosphate $\Delta$-isomerase 2

http://www.guidetopharmacology.org/GRAC/ObjectDisplayForward?objectld=647

geranylgeranyl diphosphate synthase

http://www.guidetopharmacology.org/GRAC/ObjectDisplayForward?objectld=643

farnesyl diphosphate synthase

http://www.guidetopharmacology.org/GRAC/ObjectDisplayForward?objectld=644

squalene synthase

http://www.guidetopharmacology.org/GRAC/ObjectDisplayForward?objectld=645

squalene monooxygenase

http://www.guidetopharmacology.org/GRAC/ObjectDisplayForward?objectld=2433

lanosterol synthase

http://www.guidetopharmacology.org/GRAC/ObjectDisplayForward?objectld=2434

\section{References}

1. Aboushadi N, Engfelt WH, Paton VG and Krisans SK. (1999) Role of peroxisomes in isoprenoid biosynthesis. J. Histochem. Cytochem. 47: 1127-32 [PMID:10449533]

2. Ahmad S, Madsen CS, Stein PD, Janovitz E, Huang C, Ngu K, Bisaha S, Kennedy LJ, Chen BC and Zhao $\mathrm{R}$ et al.. (2008) (3R,5S,E)-7-(4-(4-fluorophenyl)-6-isopropyl-2-(methyl(1-methyl-1h-1,2,4-triazol-5yl)amino)pyrimidin-5-yl)-3,5-dihydroxyhept-6-enoic acid (BMS-644950): a rationally designed orally efficacious 3-hydroxy-3-methylglutaryl coenzyme-a reductase inhibitor with reduced myotoxicity potential. J. Med. Chem. 51: 2722-33 [PMID:18412317]

3. Alberts AW, Chen J, Kuron G, Hunt V, Huff J, Hoffman C, Rothrock J, Lopez M, Joshua H and Harris Eet al.. (1980) Mevinolin: a highly potent competitive inhibitor of hydroxymethylglutaryl-coenzyme A reductase and a cholesterol-lowering agent. Proc. Natl. Acad. Sci. U.S.A. 77: 3957-61 [PMID:6933445]

4. Amin D, Gustafson SK, Weinacht JM, Cornell SA, Neuenschwander K, Kosmider B, Scotese AC, Regan JR and Perrone MH. (1993) RG 12561 (dalvastatin): a novel synthetic inhibitor of HMG-CoA reductase and cholesterol-lowering agent. Pharmacology 46: 13-22 [PMID:8434028]

5. Andrew Skaff D and Miziorko HM. (2010) A visible wavelength spectrophotometric assay suitable for highthroughput screening of 3-hydroxy-3-methylglutaryl-CoA synthase. Anal. Biochem. 396: 96-102 [PMID:19706283]

6. Bahmer FA and Feldmann U. (1995) Objective and reproducible assessment of irritants in vivo. A reappraisal of the IT50 in honour of Kligman and Wooding. Curr. Probl. Dermatol. 23: 288-95 [PMID:9035924]

7. Balasubramanian N, Brown PJ, Parker RA and Wright JJ. (1992) HMG-CoA Reductase Inhibitors 4. Tetrazole series: Conformational contraints and structural requirements at the hydrophobic domain. Bioorg. Med. Chem. Lett 2: 99-104 
8. Ban H, Muraoka M, loriya K and Ohashi N. (2006) Synthesis and biological activity of novel 4-phenyl-1,8naphthyridin-2(1H)-on-3-yl ureas: potent acyl-CoA:cholesterol acyltransferase inhibitor with improved aqueous solubility. Bioorg. Med. Chem. Lett. 16: 44-8 [PMID:16242323]

9. Baran JS, Laos I, Langford DD, Miller JE, Jett C, Taite B and Rohrbacher E. (1985) 3-Alkyl-3hydroxyglutaric acids: a new class of hypocholesterolemic HMG CoA reductase inhibitors. 1. J. Med. Chem. 28: 597-601 [PMID:3989819]

10. Barnard GF. (1985) Prenyltransferase from human liver. Meth. Enzymol. 110: 155-67 [PMID:4021811]

11. Barnard GF and Popják G. (1981) Human liver prenyltransferase and its characterization.Biochim. Biophys. Acta 661: 87-99 [PMID:7295734]

12. Beck G, Kesseler K, Baader E, Bartmann W, Bergmann A, Granzer E, Jendralla H, von Kerekjarto B, Krause R and Paulus E. (1990) Synthesis and biological activity of new HMG-CoA reductase inhibitors. 1. Lactones of pyridine- and pyrimidine-substituted 3,5-dihydroxy-6-heptenoic (-heptanoic) acids. J. Med. Chem. 33: 52-60 [PMID:2296036]

13. Beg ZH, Stonik JA and Brewer HB. (1979) Characterization and regulation of reductase kinase, a protein kinase that modulates the enzymic activity of 3-hydroxy-3-methylglutaryl-coenzyme A reductase. Proc. Natl. Acad. Sci. U.S.A. 76: 4375-9 [PMID:291971]

14. Bergstrom JD, Bostedor RG, Masarachia PJ, Reszka AA and Rodan G. (2000) Alendronate is a specific, nanomolar inhibitor of farnesyl diphosphate synthase. Arch. Biochem. Biophys. 373: 231-41 [PMID:10620343]

15. Bergstrom JD, Kurtz MM, Rew DJ, Amend AM, Karkas JD, Bostedor RG, Bansal VS, Dufresne C, VanMiddlesworth FL and Hensens OD. (1993) Zaragozic acids: a family of fungal metabolites that are picomolar competitive inhibitors of squalene synthase. Proc. Natl. Acad. Sci. U.S.A. 90: 80-4 [PMID:8419946]

16. Berkhout TA, Simon HM, Patel DD, Bentzen C, Niesor E, Jackson B and Suckling KE. (1996) The novel cholesterol-lowering drug SR-12813 inhibits cholesterol synthesis via an increased degradation of 3hydroxy-3-methylglutaryl-coenzyme A reductase. J. Biol. Chem. 271: 14376-82 [PMID:8662919]

17. Biller SA, Abt JW, Pudzianowski AT, Rich LC, Slusarchyk DA and Ciosek Jr CP. (1993) Aromatic isosteres as conformational probes for an isoprenyl subunit: application to inhibitors of squalene synthase. Bioorg. Med. Chem. Lett. 3: 595-600

18. Biller SA, Sofia MJ, DeLange B, Forster C, Gordon EM, Harrity T, Rich LC and Ciosek Jr CP. (1991) The First Potent Inhibitor of Squalene Synthase: A Profound Contribution of an Ether Oxygen to InhibitorEnzyme Interaction. J. Am. Chem. SOC 113: 8522-8524

19. Blanc M, Hsieh WY, Robertson KA, Watterson S, Shui G, Lacaze P, Khondoker M, Dickinson P, Sing G and Rodríguez-Martín S et al.. (2011) Host defense against viral infection involves interferon mediated down-regulation of sterol biosynthesis. PLoS Biol. 9: e1000598 [PMID:21408089]

20. Bone EA, Cunningham EM, Davidson AH, Galloway WA, Lewis CN, Morrice EM, Reeve M, Todd RS and White IM. (1992) The design and biological evaluation of a series of 3-hydroxy-3-methylglutaryl coenzyme a (HMG-CoA) reductase inhibitors related to dihydromevinolin. Bioorg. Med. Chem. Lett. 2: 223-228

21. Bone EA, Davidson AH, Lewis CN and Todd RS. (1992) Synthesis and biological evaluation of dihydroeptastatin, a novel inhibitor of 3-hydroxy-3-methylglutaryl coenzyme A reductase. J. Med. Chem. 35: 3388-93 [PMID:1527791]

22. Bouchard L, Robert MF, Vinarov D, Stanley CA, Thompson GN, Morris A, Leonard JV, Quant P, Hsu BY and Boneh A et al.. (2001) Mitochondrial 3-hydroxy-3-methylglutaryl-CoA synthase deficiency: clinical course and description of causal mutations in two patients. Pediatr. Res. 49: 326-31 [PMID:11228257]

23. Boukaftane $Y$ and Mitchell GA. (1997) Cloning and characterization of the human mitochondrial 3-hydroxy3-methylglutaryl CoA synthase gene. Gene 195: 121-6 [PMID:9305755]

24. Bratton LD, Auerbach B, Choi C, Dillon L, Hanselman JC, Larsen SD, Lu G, Olsen K, Pfefferkorn JA and Robertson A et al.. (2007) Discovery of pyrrole-based hepatoselective ligands as potent inhibitors of HMGCoA reductase. Bioorg. Med. Chem. 15: 5576-89 [PMID:17560788]

25. Breitling R, Laubner D, Clizbe D, Adamski J and Krisans SK. (2003) Isopentenyl-diphosphate isomerases 
in human and mouse: evolutionary analysis of a mammalian gene duplication. J. Mol. Evol. 57: 282-91 [PMID:14629038]

26. Brinkman JA, Damon RE, Fell JB, Perez LB, Scallen TJ and Vedamanda TR. (1996) Squalene synthase inhibitors: isosteric replacements of the farnesyl chain of benzyl farnesyl amine. Bioorg. Med. Chem. Lett. 6: $2491-2494$

27. Brown GR, Butlin RJ, Chapman S, Eakin MA, Foubister AJ, Freeman S, Griffiths D, Harrison PJ, Johnson MC and Mallion KB. (1995) Phenoxypropylamines: a new series of squalene synthase inhibitors. J. Med. Chem. 38: 4157-60 [PMID:7473541]

28. Brown GR, Clarke DS, Foubister AJ, Freeman S, Harrison PJ, Johnson MC, Mallion KB, McCormick J, McTaggart F and Reid AC et al.. (1996) Synthesis and activity of a novel series of 3-biarylquinuclidine squalene synthase inhibitors. J. Med. Chem. 39: 2971-9 [PMID:8709131]

29. Brown GR, Foubister AJ, Freeman S, McTaggart F, Mirrlees DJ, Reid AC, Smith GJ, Taylor MJ, Thomason DA and Whittamore PRO. (1997) Novel optimised quinuclidine squalene synthase inhibitors. Bioorg. Med. Chem. Lett. 7: 597-600

30. Camarero N, Mascaró C, Mayordomo C, Vilardell F, Haro D and Marrero PF. (2006) Ketogenic HMGCS2 Is a c-Myc target gene expressed in differentiated cells of human colonic epithelium and down-regulated in colon cancer. Mol. Cancer Res. 4: 645-53 [PMID:16940161]

31. Cammerer SB, Jimenez C, Jones S, Gros L, Lorente SO, Rodrigues C, Rodrigues JC, Caldera A, Ruiz Perez LM and da Souza W et al.. (2007) Quinuclidine derivatives as potential antiparasitics.Antimicrob. Agents Chemother. 51: 4049-61 [PMID:17709461]

32. Carbonell T and Freire E. (2005) Binding thermodynamics of statins to HMG-CoA reductase Biochemistry 44: 11741-8 [PMID:16128575]

33. Chambliss KL, Slaughter CA, Schreiner R, Hoffmann GF and Gibson KM. (1996) Molecular cloning of human phosphomevalonate kinase and identification of a consensus peroxisomal targeting sequence. $J$. Biol. Chem. 271: 17330-4 [PMID:8663599]

34. Chan C, Bailey EJ, Hartley CD, Hayman DF, Hutson JL, Inglis GG, Jones PS, Keeling SE, Kirk BE and Lamont RB. (1993) Inhibitors of cholesterol biosynthesis. 1. 3,5-Dihydroxy-7-(N-imidazolyl)-6-heptenoates and -heptanoates, a novel series of HMG-CoA reductase inhibitors. J. Med. Chem. 36: 3646-57 [PMID:8246233]

35. Chang Q, Yan XX, Gu SY, Liu JF and Liang DC. (2008) Crystal structure of human phosphomevalonate kinase at 1.8 A resolution. Proteins 73: 254-8 [PMID:18618710]

36. Charlton-Menys V and Durrington PN. (2007) Squalene synthase inhibitors : clinical pharmacology and cholesterol-lowering potential. Drugs 67: 11-6 [PMID:17209661]

37. Chu X and Li D. (2003) Expression, purification, and characterization of His20 mutants of rat mevalonate kinase. Protein Expr. Purif. 32: 75-82 [PMID:14680942]

38. Chu $X$ and Li D. (2003) Cloning, expression, and purification of His-tagged rat mevalonate kinase.Protein Expr. Purif. 27: 165-70 [PMID:12509999]

39. Chu X, Yu W, Wu L, Liu X, Li N and Li D. (2007) Effect of a disulfide bond on mevalonate kinaseBiochim. Biophys. Acta 1774: 1571-81 [PMID:17964869]

40. Chun KT and Simoni RD. (1992) The role of the membrane domain in the regulated degradation of 3hydroxy-3-methylglutaryl coenzyme A reductase. J. Biol. Chem. 267: 4236-46 [PMID:1740463]

41. Chun KY, Vinarov DA and Miziorko HM. (2000) 3-Hydroxy-3-methylglutaryl-CoA synthase: participation of invariant acidic residues in formation of the acetyl-S-enzyme reaction intermediate. Biochemistry 39 : 14670-81 [PMID:11087424]

42. Clizbe DB, Owens ML, Masuda KR, Shackelford JE and Krisans SK. (2007) IDI2, a second isopentenyl diphosphate isomerase in mammals. J. Biol. Chem. 282: 6668-76 [PMID:17202134]

43. Connolly PJ, Westin CD, Loughney DA and Minor LK. (1993) HMG-CoA reductase inhibitors: design, synthesis, and biological activity of tetrahydroindazole-substituted 3,5-dihydroxy-6-heptenoic acid sodium salts. J. Med. Chem. 36: 3674-85 [PMID:8246237]

44. Coppola GM, Damon RE, Yu H, Engstrom RG and Scallen TJ. (1997) Design and biological evaluation of 
a series of thiophene-based 3-hydroxy-3-methylglutaryl coenzyme a reductase inhibitors. Bioorganic \& Medicinal Chemistry Letters 7: 549-554

45. Cuisset L, Drenth JP, Simon A, Vincent MF, van der Velde Visser S, van der Meer JW, Grateau G, Delpech M and International Hyper-IgD Study Group. (2001) Molecular analysis of MVK mutations and enzymatic activity in hyper-IgD and periodic fever syndrome. Eur. J. Hum. Genet. 9: 260-6 [PMID:11313769]

46. D'Osualdo A, Picco P, Caroli F, Gattorno M, Giacchino R, Fortini P, Corona F, Tommasini A, Salvi G and Specchia F et al.. (2005) MVK mutations and associated clinical features in Italian patients affected with autoinflammatory disorders and recurrent fever. Eur. J. Hum. Genet. 13: 314-20 [PMID:15536479]

47. Deprèle S, Kashemirov BA, Hogan JM, Ebetino FH, Barnett BL, Evdokimov A and McKenna CE. (2008) Farnesyl pyrophosphate synthase enantiospecificity with a chiral risedronate analog, [6,7-dihydro-5Hcyclopenta[c]pyridin-7-yl(hydroxy)methylene]bis(phosphonic acid) (NE-10501): Synthetic, structural, and modeling studies. Bioorg. Med. Chem. Lett. 18: 2878-82 [PMID:18434151]

48. Dickschat JS. (2011) Isoprenoids in three-dimensional space: the stereochemistry of terpene biosynthesis. Nat Prod Rep 28: 1917-36 [PMID:21979838]

49. Dietschy JM, Turley SD and Spady DK. (1993) Role of liver in the maintenance of cholesterol and low density lipoprotein homeostasis in different animal species, including humans. J. Lipid Res. 34: 1637-59 [PMID:8245716]

50. Do R, Paré G, Montpetit A, Hudson TJ, Gaudet D and Engert JC. (2008) K45R variant of squalene synthase increases total cholesterol levels in two study samples from a French Canadian population. Hum. Mutat. 29: 689-94 [PMID:18350552]

51. Drenth JP, Cuisset L, Grateau G, Vasseur C, van de Velde-Visser SD, de Jong JG, Beckmann JS, van der Meer JW and Delpech M. (1999) Mutations in the gene encoding mevalonate kinase cause hyper-lgD and periodic fever syndrome. International Hyper-IgD Study Group. Nat. Genet. 22: 178-81 [PMID:10369262]

52. Dreyer GB, Garvie CT, Metcalf BW, Meek TD and Mayer RJ.. (1991) Phosphinic acid inhibitors of 3hydroxy-3-methylglutaryl-coenzyme a reductase. Bioorg. Med. Chem. Lett. 1: 152-154

53. Dufresne C, Wilson KE, Zink D, Smith J, Bergstrom JD, Kurtz M, Rew D, Nallin M, Jenkins R, Bartizal K, Trainor C, Bills G, Meinz M, Huang L, Onishi J, Milligan J, Mojena M and Pelaez F. (1992) The Isolation and Structure Elucidation of Zaragozic Acid C, a Novel Potent Squalene Synthase Inhibitor. Tetrahedron 48: 10221-10226

54. Duggan ME, Alberts AW, Bostedor R, Chao YS, Germershausen JI, Gilfillan JL, Halczenko W, Hartman GD, Hunt V and Imagire JS. (1991) 3-Hydroxy-3-methylglutaryl-coenzyme a reductase inhibitors. 7. Modification of the hexahydronaphthalene moiety of simvastatin: 5-oxygenated and 5-oxa derivatives. J. Med. Chem. 34: 2489-95 [PMID:1875346]

55. Dunford JE, Kwaasi AA, Rogers MJ, Barnett BL, Ebetino FH, Russell RG, Oppermann U and Kavanagh $\mathrm{KL}$. (2008) Structure-activity relationships among the nitrogen containing bisphosphonates in clinical use and other analogues: time-dependent inhibition of human farnesyl pyrophosphate synthase. J. Med.

Chem. 51: 2187-95 [PMID:18327899]

56. Dunford JE, Thompson K, Coxon FP, Luckman SP, Hahn FM, Poulter CD, Ebetino FH and Rogers MJ. (2001) Structure-activity relationships for inhibition of farnesyl diphosphate synthase in vitro and inhibition of bone resorption in vivo by nitrogen-containing bisphosphonates. J. Pharmacol. Exp. Ther. 296: 235-42 [PMID:11160603]

57. Endo A. (1985) Compactin (ML-236B) and related compounds as potential cholesterol-lowering agents that inhibit HMG-CoA reductase. J. Med. Chem. 28: 401-5 [PMID:3981532]

58. Ericsson J, Greene JM, Carter KC, Shell BK, Duan DR, Florence C and Edwards PA. (1998) Human geranylgeranyl diphosphate synthase: isolation of the cDNA, chromosomal mapping and tissue expression. J. Lipid Res. 39: 1731-9 [PMID:9741684]

59. Ericsson J, Runquist M, Thelin A, Andersson M, Chojnacki T and Dallner G. (1993) Distribution of prenyltransferases in rat tissues. Evidence for a cytosolic all-trans-geranylgeranyl diphosphate synthase. J. Biol. Chem. 268: 832-8 [PMID:8419360] 
60. Fakheri RJ and Javitt NB. (2011) Autoregulation of cholesterol synthesis: physiologic and pathophysiologic consequences. Steroids 76: 211-5 [PMID:20951718]

61. Frye LL, Cusack KP and Leonard DA. (1993) 32-Methyl-32-oxylanosterols: dual-action inhibitors of cholesterol biosynthesis. J. Med. Chem. 36: 410-6 [PMID:8426367]

62. Fu Z, Voynova NE, Herdendorf TJ, Miziorko HM and Kim JJ. (2008) Biochemical and structural basis for feedback inhibition of mevalonate kinase and isoprenoid metabolism. Biochemistry 47: 3715-24 [PMID:18302342]

63. Fukao T, Nakamura H, Song XQ, Nakamura K, Orii KE, Kohno Y, Kano M, Yamaguchi S, Hashimoto T and Orii T et al.. (1998) Characterization of N93S, I312T, and A333P missense mutations in two Japanese families with mitochondrial acetoacetyl-CoA thiolase deficiency. Hum. Mutat. 12: 245-54 [PMID:9744475]

64. Fukao T, Yamaguchi S, Orii T, Schutgens RB, Osumi T and Hashimoto T. (1992) Identification of three mutant alleles of the gene for mitochondrial acetoacetyl-coenzyme $A$ thiolase. A complete analysis of two generations of a family with 3-ketothiolase deficiency. J. Clin. Invest. 89: 474-9 [PMID:1346617]

65. Fukao T, Yamaguchi S, Tomatsu S, Orii T, Frauendienst-Egger G, Schrod L, Osumi T and Hashimoto T. (1991) Evidence for a structural mutation (347Ala to Thr) in a German family with 3-ketothiolase deficiency. Biochem. Biophys. Res. Commun. 179: 124-9 [PMID:1715688]

66. Fung AK, Baker WR, Fakhoury S, Stein HH, Cohen J, Donner BG, Garvey DS, Spina KP and Rosenberg SH. (1997) (1 alpha, 2 beta, 3 beta, 4 alpha)-1,2-bis[N-propyl-N-(4-phenoxybenzyl) amino]carbonyl]cyclobutane-3,4-dicarboxylic acid (A-87049): a novel potent squalene synthase inhibitor. J. Med. Chem. 40: 2123-5 [PMID:9216829]

67. Gaylor JL. (2002) Membrane-bound enzymes of cholesterol synthesis from lanosterol.Biochem. Biophys. Res. Commun. 292: 1139-46 [PMID:11969204]

68. Gibson KM, Hoffmann GF, Tanaka RD, Bishop RW and Chambliss KL. (1997) Mevalonate kinase map position 12q24. Chromosome Res. 5: 150 [PMID:9146921]

69. Gill S, Stevenson J, Kristiana I and Brown AJ. (2011) Cholesterol-dependent degradation of squalene monooxygenase, a control point in cholesterol synthesis beyond HMG-CoA reductase. Cell Metab. 13: 260-73 [PMID:21356516]

70. Glickman JF and Schmid A. (2007) Farnesyl pyrophosphate synthase: real-time kinetics and inhibition by nitrogen-containing bisphosphonates in a scintillation assay. Assay Drug Dev Technol 5: 205-14 [PMID:17477829]

71. Goldstein JL and Brown MS. (1990) Regulation of the mevalonate pathway.Nature 343: 425-30 [PMID:1967820]

72. Gotteland JP, Brunel I, Gendre F, Désiré J, Delhon A, Junquéro D, Oms P and Halazy S. (1995) (Aryloxy)methylsilane derivatives as new cholesterol biosynthesis inhibitors: synthesis and hypocholesterolemic activity of a new class of squalene epoxidase inhibitors. J. Med. Chem. 38: 3207-16 [PMID:7650673]

73. Gotteland JP, Dax C and Halazy S. (1997) Design and synthesis of new potential photoaffinity labels for mammalian squalene epoxidase. Bioorg. Med. Chem. Lett 7: 1153-1156

74. Gotteland JP, Loubat C, Planty B, Junquéro D, Delhon A and Halazy S. (1998) Sulfonamide derivatives of benzylamine block cholesterol biosynthesis in HepG2 cells: a new type of potent squalene epoxidase inhibitors. Bioorg. Med. Chem. Lett. 8: 1337-42 [PMID:9871762]

75. Greenspan MD, Bull HG, Yudkovitz JB, Hanf DP and Alberts AW. (1993) Inhibition of 3-hydroxy-3methylglutaryl-CoA synthase and cholesterol biosynthesis by beta-lactone inhibitors and binding of these inhibitors to the enzyme. Biochem. J. 289 ( Pt 3): 889-95 [PMID:8094614]

76. Greenspan MD, Yudkovitz JB, Lo CY, Chen JS, Alberts AW, Hunt VM, Chang MN, Yang SS, Thompson $\mathrm{KL}$ and Chiang YC et al.. (1987) Inhibition of hydroxymethylglutaryl-coenzyme A synthase by L-659,699. Proc. Natl. Acad. Sci. U.S.A. 84: 7488-92 [PMID:2890166]

77. Groot CJ, Haan GL, Hulstaert CE and Hoomes FA. (1977) A patient with severe neurologic symptoms and acetoacetyl-CoA thiolase deficiency. Pediatr. Res. 11: 1112-6 [PMID:20597]

78. Gueguen Y, Ferrari L, Souidi M, Batt AM, Lutton C, Siest G and Visvikis S. (2007) Compared effect of 
immunosuppressive drugs cyclosporine $A$ and rapamycin on cholesterol homeostasis key enzymes CYP27A1 and HMG-CoA reductase. Basic Clin. Pharmacol. Toxicol. 100: 392-7 [PMID:17516993]

79. Guo RT, Cao R, Liang PH, Ko TP, Chang TH, Hudock MP, Jeng WY, Chen CK, Zhang Y and Song Yet al.. (2007) Bisphosphonates target multiple sites in both cis- and trans-prenyltransferases.Proc. Natl. Acad. Sci. U.S.A. 104: 10022-7 [PMID:17535895]

80. Haapalainen AM, Meriläinen G, Pirilä PL, Kondo N, Fukao T and Wierenga RK. (2007) Crystallographic and kinetic studies of human mitochondrial acetoacetyl-CoA thiolase: the importance of potassium and chloride ions for its structure and function. Biochemistry 46: 4305-21 [PMID:17371050]

81. Hahn FM, Xuan JW, Chambers AF and Poulter CD. (1996) Human isopentenyl diphosphate: dimethylallyl diphosphate isomerase: overproduction, purification, and characterization. Arch. Biochem. Biophys. 332: 30-4 [PMID:8806705]

82. Harris GH, Dufresne C, Joshua H, Koch LA, Zink DL, Salmon PM, Göklen KE, Kurtz MM, Rew DJ, Bergstrom JD and Wilson KE. (1995) Isolation, structure determination and squalene synthase activity of L-731,120 and L-731,128, alkyl citrate analogs of zaragozic acids A and B. Bioorg. Med. Chem. Lett. 5: 2403-2408

83. Hartman GD, Halczenko W, Duggan ME, Imagire JS, Smith RL, Pitzenberger SM, Fitzpatrick SL, Alberts AW, Bostedor R and Chao YS. (1992) 3-Hydroxy-3-methylglutaryl-coenzyme A reductase inhibitors. 9. The synthesis and biological evaluation of novel simvastatin analogs. J. Med. Chem. 35: 3813-21 [PMID:1433193]

84. Heathcock CH, Davis BR and Hadley CR. (1989) Synthesis and biological evaluation of a monocyclic, fully functional analogue of compactin. J. Med. Chem. 32: 197-202 [PMID:2909732]

85. Heathcock CH, Hadley CR, Rosen T, Theisen PD and Hecker SJ. (1987) Total synthesis and biological evaluation of structural analogues of compactin and dihydromevinolin. J. Med. Chem. 30: 1858-73 [PMID:3656359]

86. Herdendorf TJ and Miziorko HM. (2007) Functional evaluation of conserved basic residues in human phosphomevalonate kinase. Biochemistry 46: 11780-8 [PMID:17902708]

87. Herdendorf TJ and Miziorko HM. (2006) Phosphomevalonate kinase: functional investigation of the recombinant human enzyme. Biochemistry 45: 3235-42 [PMID:16519518]

88. Herman GE. (2003) Disorders of cholesterol biosynthesis: prototypic metabolic malformation syndromes. Hum. Mol. Genet. 12 Spec No 1: R75-88 [PMID:12668600]

89. Hinson DD, Chambliss KL, Toth MJ, Tanaka RD and Gibson KM. (1997) Post-translational regulation of mevalonate kinase by intermediates of the cholesterol and nonsterol isoprene biosynthetic pathways. $J$. Lipid Res. 38: 2216-23 [PMID:9392419]

90. Hinson DD, Ross RM, Krisans S, Shaw JL, Kozich V, Rolland MO, Divry P, Mancini J, Hoffmann GF and Gibson KM. (1999) Identification of a mutation cluster in mevalonate kinase deficiency, including a new mutation in a patient of Mennonite ancestry. Am. J. Hum. Genet. 65: 327-35 [PMID:10417275]

91. Hoffman WF, Alberts AW, Anderson PS, Chen JS, Smith RL and Willard AK. (1986) 3-Hydroxy-3methylglutaryl-coenzyme A reductase inhibitors. 4. Side chain ester derivatives of mevinolin. J. Med. Chem. 29: 849-52 [PMID:3634830]

92. Hoffmann F, Lohse P, Stojanov S, Shin YS, Renner ED, Kéry A, Zellerer S and Belohradsky BH. (2005) Identification of a novel mevalonate kinase gene mutation in combination with the common MVK V377I substitution and the low-penetrance TNFRSF1A R92Q mutation. Eur. J. Hum. Genet. 13: 510-2 [PMID:15657603]

93. Hoffmann G, Gibson KM, Brandt IK, Bader PI, Wappner RS and Sweetman L. (1986) Mevalonic aciduria-an inborn error of cholesterol and nonsterol isoprene biosynthesis. N. Engl. J. Med. 314: 1610-4 [PMID:3012338]

94. Hoffmann GF, Charpentier C, Mayatepek E, Mancini J, Leichsenring M, Gibson KM, Divry P, Hrebicek M, Lehnert W and Sartor K. (1993) Clinical and biochemical phenotype in 11 patients with mevalonic aciduria. Pediatrics 91: 915-21 [PMID:8386351]

95. Hogenboom S, Tuyp JJ, Espeel M, Koster J, Wanders RJ and Waterham HR. (2004) Mevalonate kinase is 
a cytosolic enzyme in humans. J. Cell. Sci. 117: 631-9 [PMID:14730012]

96. Holdgate GA, Ward WH and McTaggart F. (2003) Molecular mechanism for inhibition of 3-hydroxy-3methylglutaryl CoA (HMG-CoA) reductase by rosuvastatin. Biochem. Soc. Trans. 31: 528-31 [PMID:12773150]

97. Horvat S, McWhir J and Rozman D. (2011) Defects in cholesterol synthesis genes in mouse and in humans: lessons for drug development and safer treatments. Drug Metab. Rev. 43: 69-90 [PMID:21247357]

98. Hosoda S, Matsuda D, Tomoda H, Hashimoto M, Aoyama H and Hashimoto Y. (2009) Application of a 3,3diphenylpentane skeleton as a multi-template for creation of HMG-CoA reductase inhibitors. Bioorg. Med. Chem. Lett. 19: 4228-31 [PMID:19502059]

99. Houten SM, Frenkel J, Rijkers GT, Wanders RJ, Kuis W and Waterham HR. (2002) Temperature dependence of mutant mevalonate kinase activity as a pathogenic factor in hyper-lgD and periodic fever syndrome. Hum. Mol. Genet. 11: 3115-24 [PMID:12444096]

100. Houten SM, Frenkel $\mathrm{J}$ and Waterham HR. (2003) Isoprenoid biosynthesis in hereditary periodic fever syndromes and inflammation. Cell. Mol. Life Sci. 60: 1118-34 [PMID:12861380]

101. Houten SM, Koster J, Romeijn GJ, Frenkel J, Di Rocco M, Caruso U, Landrieu P, Kelley RI, Kuis W and Poll-The BT et al.. (2001) Organization of the mevalonate kinase (MVK) gene and identification of novel mutations causing mevalonic aciduria and hyperimmunoglobulinaemia $D$ and periodic fever syndrome. Eur. J. Hum. Genet. 9: 253-9 [PMID:11313768]

102. Houten SM, Kuis W, Duran M, de Koning TJ, van Royen-Kerkhof A, Romeijn GJ, Frenkel J, Dorland L, de Barse MM and Huijbers WA et al.. (1999) Mutations in MVK, encoding mevalonate kinase, cause hyperimmunoglobulinaemia D and periodic fever syndrome. Nat. Genet. 22: 175-7 [PMID:10369261]

103. Houten SM, Romeijn GJ, Koster J, Gray RG, Darbyshire P, Smit GP, de Klerk JB, Duran M, Gibson KM and Wanders RJ et al.. (1999) Identification and characterization of three novel missense mutations in mevalonate kinase cDNA causing mevalonic aciduria, a disorder of isoprene biosynthesis. Hum. Mol. Genet. 8: 1523-8 [PMID:10401001]

104. Ichikawa M, Ohtsuka M, Ohki H, Haginoya N, Itoh M, Sugita K, Usui H, Suzuki M, Terayama K and Kanda A. (2012) Discovery of novel tricyclic compounds as squalene synthase inhibitors. Bioorg. Med. Chem. 20: 3072-93 [PMID:22464687]

105. Ingebritsen TS, Parker RA and Gibson DM. (1981) Regulation of liver hydroxymethylglutaryl-CoA reductase by a bicyclic phosphorylation system. J. Biol. Chem. 256: 1138-44 [PMID:6256385]

106. Ishihara T, Kakuta H, Moritani H, Ugawa T and Yanagisawa I. (2004) Synthesis and biological evaluation of novel propylamine derivatives as orally active squalene synthase inhibitors. Bioorg. Med. Chem. 12: 5899-908 [PMID:15498666]

107. Istvan ES and Deisenhofer J. (2000) The structure of the catalytic portion of human HMG-CoA reductase. Biochim. Biophys. Acta 1529: 9-18 [PMID:11111074]

108. Istvan ES and Deisenhofer J. (2001) Structural mechanism for statin inhibition of HMG-CoA reductase. Science 292: 1160-4 [PMID:11349148]

109. Imasawa Y, Hayashi M, Nomoto T, Shibata J, Mitsuya M, Hirota K, Yonemoto M, Kamei T, Miura K and Tomimoto K. (1995) Synthesis and biological activity of J-104,118, a novel, potent inhibitor of squalene synthase. Bioorg. Med. Chem. Lett. 5: 1989-1994

110. Iwasawa Y, Shibata J, Mitsuya M, Masaki H, Hayashi M, Kanno T, Sawasaki Y, Hisaka A, Kamei T and Tomimoto K. (1996) J-104,123, a novel and orally-active inhibitor of squalene synthase: Stereoselective synthesis and cholesterol lowering effects in dogs. Bioorg. Med. Chem. Lett. 6: 463-466

111. Jendralla H, Baader E, Bartmann W, Beck G, Bergmann A, Granzer E, von Kerekjarto B, Kesseler K, Krause $R$ and Schubert W. (1990) Synthesis and biological activity of new HMG-CoA reductase inhibitors. 2. Derivatives of 7-(1H-pyrrol-3-yl)-substituted-3,5-dihydroxyhept-6(E)-enoic (-heptanoic) acids. J. Med. Chem. 33: 61-70 [PMID:2153213]

112. Jendralla H, Granzer E, von Kerekjarto B, Krause R, Schacht U, Baader E, Bartmann W, Beck G, Bergmann A and Kesseler K. (1991) Synthesis and biological activity of new HMG-CoA reductase 
inhibitors. 3. Lactones of 6-phenoxy-3,5-dihydroxyhexanoic acids. J. Med. Chem. 34: 2962-83 [PMID:1656041]

113. Jiang G, McKenzie TL, Conrad DG and Shechter I. (1993) Transcriptional regulation by lovastatin and 25hydroxycholesterol in HepG2 cells and molecular cloning and expression of the cDNA for the human hepatic squalene synthase. J. Biol. Chem. 268: 12818-24 [PMID:7685352]

114. Jingami H, Brown MS, Goldstein JL, Anderson RG and Luskey KL. (1987) Partial deletion of membranebound domain of 3-hydroxy-3-methylglutaryl coenzyme A reductase eliminates sterol-enhanced degradation and prevents formation of crystalloid endoplasmic reticulum. J. Cell Biol. 104: 1693-704 [PMID:3584246]

115. K-M Chen C, Hudock MP, Zhang Y, Guo RT, Cao R, No JH, Liang PH, Ko TP, Chang TH and Chang SC et al.. (2008) Inhibition of geranylgeranyl diphosphate synthase by bisphosphonates: a crystallographic and computational investigation. J. Med. Chem. 51: 5594-607 [PMID:18800762]

116. Karanewsky DS, Badia MC, Ciosek CP, Robl JA, Sofia MJ, Simpkins LM, DeLange B, Harrity TW, Biller SA and Gordon EM. (1990) Phosphorus-containing inhibitors of HMG-CoA reductase. 1. 4-[(2arylethyl)hydroxyphosphinyl]-3-hydroxy-butanoic acids: a new class of cell-selective inhibitors of cholesterol biosynthesis. J. Med. Chem. 33: 2952-6 [PMID:2231594]

117. Kato T, Emi M, Sato H, Arawaka S, Wada M, Kawanami T, Katagiri T, Tsuburaya K, Toyoshima I and Tanaka F et al.. (2010) Segmental copy-number gain within the region of isopentenyl diphosphate isomerase genes in sporadic amyotrophic lateral sclerosis. Biochem. Biophys. Res. Commun. 402: 438-42 [PMID:20955688]

118. Kavanagh KL, Dunford JE, Bunkoczi G, Russell RG and Oppermann U. (2006) The crystal structure of human geranylgeranyl pyrophosphate synthase reveals a novel hexameric arrangement and inhibitory product binding. J. Biol. Chem. 281: 22004-12 [PMID:16698791]

119. Kawachi T and Rudney H. (1970) Solubilization and purification of beta-hydroxy-beta-methylglutaryl coenzyme A reductase from rat liver. Biochemistry 9: 1700-5 [PMID:4985697]

120. Kourounakis AP, Charitos C, Rekka EA and Kourounakis PN. (2008) Lipid-lowering (hetero)aromatic tetrahydro-1,4-oxazine derivatives with antioxidant and squalene synthase inhibitory activity. J. Med. Chem. 51: 5861-5 [PMID:18754614]

121. Kovacs WJ, Tape KN, Shackelford JE, Duan X, Kasumov T, Kelleher JK, Brunengraber H and Krisans SK. (2007) Localization of the pre-squalene segment of the isoprenoid biosynthetic pathway in mammalian peroxisomes. Histochem. Cell Biol. 127: 273-90 [PMID:17180682]

122. Laden BP, Tang $Y$ and Porter TD. (2000) Cloning, heterologous expression, and enzymological characterization of human squalene monooxygenase. Arch. Biochem. Biophys. 374: 381-8 [PMID:10666321]

123. Lin FY, Liu YL, Li K, Cao R, Zhu W, Axelson J, Pang R and Oldfield E. (2012) Head-to-head prenyl tranferases: anti-infective drug targets. J. Med. Chem. 55: 4367-72 [PMID:22486710]

124. Lin YS, Park J, De Schutter JW, Huang XF, Berghuis AM, Sebag M and Tsantrizos YS. (2012) Design and synthesis of active site inhibitors of the human farnesyl pyrophosphate synthase: apoptosis and inhibition of ERK phosphorylation in multiple myeloma cells. J. Med. Chem. 55: 3201-15 [PMID:22390415]

125. Lindgren V, Luskey KL, Russell DW and Francke U. (1985) Human genes involved in cholesterol metabolism: chromosomal mapping of the loci for the low density lipoprotein receptor and 3-hydroxy-3methylglutaryl-coenzyme A reductase with cDNA probes. Proc. Natl. Acad. Sci. U.S.A. 82: 8567-71 [PMID:3866240]

126. Liu Cl, Jeng WY, Chang WJ, Ko TP and Wang AH. (2012) Binding modes of zaragozic acid A to human squalene synthase and staphylococcal dehydrosqualene synthase. J. Biol. Chem. 287: 18750-7 [PMID:22474324]

127. Lolli ML, Rolando B, Tosco P, Chaurasia S, Di Stilo A, Lazzarato L, Gorassini E, Ferracini R, Oliaro-Bosso $S$ and Fruttero $R$ et al.. (2010) Synthesis and preliminary pharmacological characterisation of a new class of nitrogen-containing bisphosphonates (N-BPs). Bioorg. Med. Chem. 18: 2428-38 [PMID:20299227]

128. Lühe A, Künkele KP, Haiker M, Schad K, Zihlmann C, Bauss F, Suter L and Pfister T. (2008) Preclinical 
evidence for nitrogen-containing bisphosphonate inhibition of farnesyl diphosphate (FPP) synthase in the kidney: implications for renal safety. Toxicol In Vitro 22: 899-909 [PMID:18325729]

129. Maggo SD, Kennedy MA and Clark DW. (2011) Clinical implications of pharmacogenetic variation on the effects of statins. Drug Saf 34: 1-19 [PMID:21142270]

130. Magnin DR, Biller SA, Chen Y, Dickson JK, Fryszman OM, Lawrence RM, Logan JV, Sieber-McMaster ES, Sulsky RB and Traeger SC et al.. (1996) alpha-Phosphonosulfonic acids: potent and selective inhibitors of squalene synthase. J. Med. Chem. 39: 657-60 [PMID:8576905]

131. Magnin DR, Biller SA, Dickson JK, Logan JV, Lawrence RM, Chen Y, Sulsky RB, Ciosek CP, Harrity TW and Jolibois KG. (1995) 1,1-Bisphosphonate squalene synthase inhibitors: interplay between the isoprenoid subunit and the diphosphate surrogate. J. Med. Chem. 38: 2596-605 [PMID:7629799]

132. Marma MS, Xia Z, Stewart C, Coxon F, Dunford JE, Baron R, Kashemirov BA, Ebetino FH, Triffitt JT and Russell RG et al.. (2007) Synthesis and biological evaluation of alpha-halogenated bisphosphonate and phosphonocarboxylate analogues of risedronate. J. Med. Chem. 50: 5967-75 [PMID:17975902]

133. Marquart AL, Schatzman GL, Peet NP, Moore WR, Huber EW, Gallion SL and Angelastro MR. (1994) Inhibition of oxidosqualene cyclase by substituted quinolizidines. Bioorg. Med. Chem. Lett. 4: 1317-1318

134. Mascaró C, Buesa C, Ortiz JA, Haro D and Hegardt FG. (1995) Molecular cloning and tissue expression of human mitochondrial 3-hydroxy-3-methylglutaryl-CoA synthase. Arch. Biochem. Biophys. 317: 385-90 [PMID:7893153]

135. Masuno M, Fukao T, Song XQ, Yamaguchi S, Orii T, Kondo N, Imaizumi K and Kuroki Y. (1996) Assignment of the human cytosolic acetoacetyl-coenzyme A thiolase (ACAT2) gene to chromosome 6q25.3-q26. Genomics 36: 217-8 [PMID:8812443]

136. Matsumura Y, Kidokoro T, Miyagi Y, Marilingaiah NR and Sagami H. (2007) The carboxyl-terminal region of the geranylgeranyl diphosphate synthase is indispensable for the stabilization of the region involved in substrate binding and catalysis. J. Biochem. 142: 533-7 [PMID:17846065]

137. Matsumura Y, Kuzuguchi T and Sagami H. (2004) Relationship between intron $4 \mathrm{~b}$ splicing of the rat geranylgeranyl diphosphate synthase gene and the active enzyme expression level. J. Biochem. 136: 30112 [PMID:15598886]

138. McKenna CE, Kashemirov BA, Błazewska KM, Mallard-Favier I, Stewart CA, Rojas J, Lundy MW, Ebetino FH, Baron RA and Dunford JE et al.. (2010) Synthesis, chiral high performance liquid chromatographic resolution and enantiospecific activity of a potent new geranylgeranyl transferase inhibitor, 2-hydroxy-3imidazo[1,2-a]pyridin-3-yl-2-phosphonopropionic acid. J. Med. Chem. 53: 3454-64 [PMID:20394422]

139. McTaggart F, Buckett L, Davidson R, Holdgate G, McCormick A, Schneck D, Smith G and Warwick M. (2001) Preclinical and clinical pharmacology of Rosuvastatin, a new 3-hydroxy-3-methylglutaryl coenzyme A reductase inhibitor. Am. J. Cardiol. 87: 28B-32B [PMID:11256847]

140. Michihara A, Akasaki K, Yamori $Y$ and Tsuji H. (2002) Purification and characterization of mouse mevalonate pyrophosphate decarboxylase. Biol. Pharm. Bull. 25: 302-6 [PMID:11913522]

141. Michihara A, Sawamura M, Nara Y, Ikeda K and Yamori Y. (1997) Purification and characterization of two mevalonate pyrophosphate decarboxylases from rat liver: a novel molecular species of $37 \mathrm{kDa}$. J. Biochem. 122: 647-54 [PMID:9348097]

142. Miki T, Kori M, Mabuchi H, Tozawa R, Nishimoto T, Sugiyama Y, Teshima K and Yukimasa H. (2002) Synthesis of novel 4,1-benzoxazepine derivatives as squalene synthase inhibitors and their inhibition of cholesterol synthesis. J. Med. Chem. 45: 4571-80 [PMID:12238936]

143. Miziorko HM. (2011) Enzymes of the mevalonate pathway of isoprenoid biosynthesis.Arch. Biochem. Biophys. 505: 131-43 [PMID:20932952]

144. Morikawa S, Murakami T, Yamazaki H, Izumi A, Saito Y, Hamakubo T and Kodama T. (2005) Analysis of the global RNA expression profiles of skeletal muscle cells treated with statins. J. Atheroscler. Thromb. 12: 121-31 [PMID:16020911]

145. Murphy C, Murray AM, Meaney S and Gåfvels M. (2007) Regulation by SREBP-2 defines a potential link between isoprenoid and adenosylcobalamin metabolism. Biochem. Biophys. Res. Commun. 355: 359-64 [PMID:17300749] 
146. Nagai M, Sakakibara J, Wakui K, Fukushima Y, Igarashi S, Tsuji S, Arakawa M and Ono T. (1997) Localization of the squalene epoxidase gene (SQLE) to human chromosome region 8q24.1. Genomics 44: 141-3 [PMID:9286711]

147. Ness GC, Eales SJ, Pendleton LC and Smith M. (1985) Activation of rat liver microsomal 3-hydroxy-3methylglutaryl coenzyme A reductase by NADPH. Effects of dietary treatments. J. Biol. Chem. 260: 123913 [PMID:3850089]

148. Obiol-Pardo C, Rubio-Martinez J and Imperial S. (2011) The methylerythritol phosphate (MEP) pathway for isoprenoid biosynthesis as a target for the development of new drugs against tuberculosis. Curr. Med. Chem. 18: 1325-38 [PMID:21366531]

149. Olender EH and Simon RD. (1992) The intracellular targeting and membrane topology of 3-hydroxy-3methylglutaryl-CoA reductase. J. Biol. Chem. 267: 4223-35 [PMID:1740462]

150. Olivier LM, Chambliss KL, Gibson KM and Krisans SK. (1999) Characterization of phosphomevalonate kinase: chromosomal localization, regulation, and subcellular targeting. J. Lipid Res. 40: 672-9 [PMID:10191291]

151. Overhand M, Pieterman E, Cohen LH, Valentijn ARPM, van der Marel GA and van Boom JH. (1997) Synthesis of triphosphonate analogues of farnesyl pyrophosphate. Inhibitors of squalene synthase and protein:farnesyl transferase. Bioorg. Med. Chem. Lett. 7: 2435-2440

152. Pak VV, Koo M, Kwon DY, Shakhidoyatov KM and Yun L. (2010) Peptide fragmentation as an approach in modeling of an active peptide and designing a competitive inhibitory peptide for HMG-CoA reductase. Bioorg. Med. Chem. 18: 4300-9 [PMID:20494585]

153. Pallottini V, Martini C, Bassi AM, Romano P, Nanni G and Trentalance A. (2006) Rat HMGCoA reductase activation in thioacetamide-induced liver injury is related to an increased reactive oxygen species content. J. Hepatol. 44: 368-74 [PMID:16140414]

154. Park WK, Kennedy RM, Larsen SD, Miller S, Roth BD, Song Y, Steinbaugh BA, Sun K, Tait BD and Kowala MC et al.. (2008) Hepatoselectivity of statins: design and synthesis of 4-sulfamoyl pyrroles as HMG-CoA reductase inhibitors. Bioorg. Med. Chem. Lett. 18: 1151-6 [PMID:18155906]

155. Patel DV and Gordon EM. (1991) C-2 desmethyl seco-mevinic acids. Monocyclic HMG-CoA reductase inhibitors. Bioorganic \& Medicinal Chemistry Letters 1: 509-512

156. Patil AD, ChanJA, Lois-Flamberg P, Mayer RJ and Westley JW. (1989) Novel Acetylenic Acids from the Root Bark of Paramacrolobium caeruleum: Inhibitors of 3-Hydroxy-3-methyl-glutaryl Coenzyme A Reductase. J. Nat. Prod. 52: 153-161

157. Peukert S, Sun Y, Zhang R, Hurley B, Sabio M, Shen X, Gray C, Dzink-Fox J, Tao J and Cebula Pet al.. (2008) Design and structure-activity relationships of potent and selective inhibitors of undecaprenyl pyrophosphate synthase (UPPS): tetramic, tetronic acids and dihydropyridin-2-ones. Bioorg. Med. Chem. Lett. 18: 1840-4 [PMID:18295483]

158. Pfefferkorn JA, Choi C, Larsen SD, Auerbach B, Hutchings R, Park W, Askew V, Dillon L, Hanselman JC and Lin $Z$ et al.. (2008) Substituted pyrazoles as hepatoselective HMG-CoA reductase inhibitors: discovery of (3R,5R)-7-[2-(4-fluoro-phenyl)-4-isopropyl-5-(4-methyl-benzylcarbamoyl)-2H-pyrazol-3-yl]-3,5dihydroxyheptanoic acid (PF-3052334) as a candidate for the treatment of hypercholesterolemia. J. Med. Chem. 51: 31-45 [PMID:18072721]

159. Pfefferkorn JA, Choi C, Song Y, Trivedi BK, Larsen SD, Askew V, Dillon L, Hanselman JC, Lin Z and Lu G et al.. (2007) Design and synthesis of novel, conformationally restricted HMG-CoA reductase inhibitors. Bioorg. Med. Chem. Lett. 17: 4531-7 [PMID:17574411]

160. Pfefferkorn JA, Song Y, Sun KL, Miller SR, Trivedi BK, Choi C, Sorenson RJ, Bratton LD, Unangst PC and Larsen SD et al.. (2007) Design and synthesis of hepatoselective, pyrrole-based HMG-CoA reductase inhibitors. Bioorg. Med. Chem. Lett. 17: 4538-44 [PMID:17574412]

161. Polo M, de Bravo MG and Carbone C. (1999) 3-Hydroxy-3-methylglutaryl coenzyme a reductase activity in liver of athymic mice with or without an implanted human carcinoma. Comp. Biochem. Physiol. B, Biochem. Mol. Biol. 122: $433-7$ [PMID:10392455]

162. Ponpipom MM, Girotra NN, Bugianesi RL, Roberts CD, Berger GD, Burk RM, Marquis RW, Parsons WH, 
Bartizal KF and Bergstom JD. (1994) Structure-activity relationships of C1 and C6 side chains of zaragozic acid A derivatives. J. Med. Chem. 37: 4031-51 [PMID:7966163]

163. Popjak G, Parker TS, Sarin V, Tropp BE and Engel R. (1978) Inhibition of 5-phosphomevalonate kinase by an isosteric analog of 5-phosphomevalonate. J. Am. Chem. Soc. 100: 8014-8016

164. Potter D and Miziorko HM. (1997) Identification of catalytic residues in human mevalonate kinase.J. Biol. Chem. 272: 25449-54 [PMID:9325256]

165. Potter D, Wojnar JM, Narasimhan C and Miziorko HM. (1997) Identification and functional characterization of an active-site lysine in mevalonate kinase. J. Biol. Chem. 272: 5741-6 [PMID:9038186]

166. Prashad M. (1993) Amidinium cation as a mimic of allylic carbocation: synthesis and squalene synthetase inhibitory activity of an amidinium analog of a carbocation intermediate. J. Med. Chem. 36: 631-2 [PMID:8496942]

167. Prashad M, Kathawala FG and Scallen T. (1993) N-(arylalkyl)farnesylamines: new potent squalene synthetase inhibitors. J. Med. Chem. 36: 1501-4 [PMID:8496919]

168. Procopiou PA, Draper CD, Hutson JL, Inglis GG, Ross BC and Watson NS. (1993) Inhibitors of cholesterol biosynthesis. 2. 3,5-Dihydroxy-7-(N-pyrrolyl)-6-heptenoates, a novel series of HMG-CoA reductase inhibitors. J. Med. Chem. 36: 3658-62 [PMID:8246234]

169. Puisac B, Ramos M, Arnedo M, Menao S, Gil-Rodríguez MC, Teresa-Rodrigo ME, Pié A, de Karam JC, Wesselink JJ and Giménez I et al.. (2012) Characterization of splice variants of the genes encoding human mitochondrial HMG-CoA lyase and HMG-CoA synthase, the main enzymes of the ketogenesis pathway. Mol. Biol. Rep. 39: 4777-85 [PMID:21952825]

170. Qiu Y, Gao J, Guo F, Qiao Y and Li D. (2007) Mutation and inhibition studies of mevalonate 5-diphosphate decarboxylase. Bioorg. Med. Chem. Lett. 17: 6164-8 [PMID:17888661]

171. Qiu Y and Li D. (2006) Inhibition of mevalonate 5-diphosphate decarboxylase by fluorinated substrate analogs. Biochim. Biophys. Acta 1760: 1080-7 [PMID:16626865]

172. Qiu Y and Li D. (2006) Bifunctional inhibitors of mevalonate kinase and mevalonate 5-diphosphate decarboxylase. Org. Lett. 8: 1013-6 [PMID:16524256]

173. Robl JA, Duncan LA, Pluscec J, Karanewsky DS, Gordon EM, Ciosek CP, Rich LC, Dehmel VC, Slusarchyk DA and Harrity TW. (1991) Phosphorus-containing inhibitors of HMG-CoA reductase. 2. Synthesis and biological activities of a series of substituted pyridines containing a hydroxyphosphinyl moiety. J. Med. Chem. 34: 2804-15 [PMID:1895299]

174. Roitelman J, Olender EH, Bar-Nun S, Dunn WA and Simoni RD. (1992) Immunological evidence for eight spans in the membrane domain of 3-hydroxy-3-methylglutaryl coenzyme A reductase: implications for enzyme degradation in the endoplasmic reticulum. J. Cell Biol. 117: 959-73 [PMID:1374417]

175. Rokosz LL, Boulton DA, Butkiewicz EA, Sanyal G, Cueto MA, Lachance PA and Hermes JD. (1994) Human cytoplasmic 3-hydroxy-3-methylglutaryl coenzyme A synthase: expression, purification, and characterization of recombinant wild-type and Cys129 mutant enzymes. Arch. Biochem. Biophys. 312: 113 [PMID:7913309]

176. Rondeau JM, Bitsch F, Bourgier E, Geiser M, Hemmig R, Kroemer M, Lehmann S, Ramage P, Rieffel S and Strauss A et al.. (2006) Structural basis for the exceptional in vivo efficacy of bisphosphonate drugs. ChemMedChem 1: 267-73 [PMID:16892359]

177. Roth BD, Blankley CJ, Chucholowski AW, Ferguson E, Hoefle ML, Ortwine DF, Newton RS, Sekerke CS, Sliskovic DR and Stratton CD. (1991) Inhibitors of cholesterol biosynthesis. 3. Tetrahydro-4-hydroxy-6-[2(1H-pyrrol-1-yl)ethyl]-2H-pyran-2-one inhibitors of HMG-CoA reductase. 2. Effects of introducing substituents at positions three and four of the pyrrole nucleus. J. Med. Chem. 34: 357-66 [PMID:1992137]

178. Roth BD, Bocan TM, Blankley CJ, Chucholowski AW, Creger PL, Creswell MW, Ferguson E, Newton RS, O'Brien P and Picard JA. (1991) Relationship between tissue selectivity and lipophilicity for inhibitors of HMG-CoA reductase. J. Med. Chem. 34: 463-6 [PMID:1992149]

179. Runquist M, Ericsson J, Thelin A, Chojnacki T and Dallner G. (1994) Isoprenoid biosynthesis in rat liver mitochondria. Studies on farnesyl pyrophosphate synthase and trans-prenyltransferase. J. Biol. Chem.

269: 5804-9 [PMID:8119922] 
180. Sarver RW, Bills E, Bolton G, Bratton LD, Caspers NL, Dunbar JB, Harris MS, Hutchings RH, Kennedy RM and Larsen SD et al.. (2008) Thermodynamic and structure guided design of statin based inhibitors of 3-hydroxy-3-methylglutaryl coenzyme A reductase. J. Med. Chem. 51: 3804-13 [PMID:18540668]

181. Schafer BL, Bishop RW, Kratunis VJ, Kalinowski SS, Mosley ST, Gibson KM and Tanaka RD. (1992) Molecular cloning of human mevalonate kinase and identification of a missense mutation in the genetic disease mevalonic aciduria. J. Biol. Chem. 267: 13229-38 [PMID:1377680]

182. Schechter I, Conrad DG, Hart I, Berger RC, McKenzie TL, Bleskan J and Patterson D. (1994) Localization of the squalene synthase gene (FDFT1) to human chromosome 8p22-p23.1. Genomics 20: 116-8 [PMID:8020937]

183. Schiefelbein D, Goren I, Fisslthaler B, Schmidt H, Geisslinger G, Pfeilschifter J and Frank S. (2008) Biphasic regulation of HMG-CoA reductase expression and activity during wound healing and its functional role in the control of keratinocyte angiogenic and proliferative responses. J. Biol. Chem. 283: 15479-90 [PMID:18390541]

184. Sealey-Cardona M, Cammerer S, Jones S, Ruiz-Pérez LM, Brun R, Gilbert IH, Urbina JA and GonzálezPacanowska D. (2007) Kinetic characterization of squalene synthase from Trypanosoma cruzi: selective inhibition by quinuclidine derivatives. Antimicrob. Agents Chemother. 51: 2123-9 [PMID:17371809]

185. Seiki S and Frishman WH. (2009) Pharmacologic inhibition of squalene synthase and other downstream enzymes of the cholesterol synthesis pathway: a new therapeutic approach to treatment of hypercholesterolemia. Cardiol Rev 17: 70-6 [PMID:19367148]

186. Shafqat N, Turnbull A, Zschocke J, Oppermann U and Yue WW. (2010) Crystal structures of human HMGCoA synthase isoforms provide insights into inherited ketogenesis disorders and inhibitor design. J. Mol. Biol. 398: 497-506 [PMID:20346956]

187. Shama Bhat $C$ and Ramasarma T. (1979) Inhibition of rat liver mevalonate pyrophosphate decarboxylase and mevalonate phosphate kinase by phenyl and phenolic compounds. Biochem. J. 181: 143-51 [PMID:226078]

188. Sharratt PJ, Hutson JL, Inglis GGA, Lester MG, Procopiou PA and Watson NS. (1994) Structurally simplified squalestatins: monocyclic 1,3-dioxane analogues. Bioorg. Med. Chem. Lett. 4: 661-666

189. Sheares BT, White SS, Molowa DT, Chan K, Ding VD, Kroon PA, Bostedor RG and Karkas JD. (1989) Cloning, analysis, and bacterial expression of human farnesyl pyrophosphate synthetase and its regulation in Hep G2 cells. Biochemistry 28: 8129-35 [PMID:2690933]

190. Shechter I, Gu P, Jiang G, Onofrey TJ, Cann RO, Castro A and Spencer TA. (1996) Sulfobetaine zwitterionic inhibitors of squalene synthase. Bioorg. Med. Chem. Lett. 6: 2585-2588

191. Shechter I, Klinger E, Rucker ML, Engstrom RG, Spirito JA, Islam MA, Boettcher BR and Weinstein DB. (1992) Solubilization, purification, and characterization of a truncated form of rat hepatic squalene synthetase. J. Biol. Chem. 267: 8628-35 [PMID:1569107]

192. Shen W, Garvey DS, Cohen J, Stein H and Rosenberg SH. (1998) Cyclopentanedi- and tricarboxylic acids as squalene synthase inhibitors: syntheses and evaluation. Bioorg. Med. Chem. Lett. 8: 891-6 [PMID:9871507]

193. Simoni D, Gebbia N, Invidiata FP, Eleopra M, Marchetti P, Rondanin R, Baruchello R, Provera S, Marchioro $\mathrm{C}$ and Tolomeo $\mathrm{M}$ et al.. (2008) Design, synthesis, and biological evaluation of novel aminobisphosphonates possessing an in vivo antitumor activity through a gammadelta-T lymphocytesmediated activation mechanism. J. Med. Chem. 51: 6800-7 [PMID:18937434]

194. Sit SY, Parker RA, Motoc I, Han W, Balasubramanian N, Catt JD, Brown PJ, Harte WE, Thompson MD and Wright JJ. (1990) Synthesis, biological profile, and quantitative structure-activity relationship of a series of novel 3-hydroxy-3-methylglutaryl coenzyme A reductase inhibitors. J. Med. Chem. 33: 2982-99 [PMID:2231596]

195. Sitthithaworn W, Kojima N, Viroonchatapan E, Suh DY, Iwanami N, Hayashi T, Noji M, Saito K, Niwa Y and Sankawa U. (2001) Geranylgeranyl diphosphate synthase from Scoparia dulcis and Croton sublyratus. Plastid localization and conversion to a farnesyl diphosphate synthase by mutagenesis. Chem. Pharm. Bull. 49: 197-202 [PMID:11217109] 
196. Sliskovic DR, Blankley CJ, Krause BR, Newton RS, Picard JA, Roark WH, Roth BD, Sekerke C, Shaw MK and Stanfield RL. (1992) Inhibitors of cholesterol biosynthesis. 6. trans-6-[2-(2-N-heteroaryl-3,5disubstituted- pyrazol-4-yl)ethyl/ethenyl]tetrahydro-4-hydroxy-2H-pyran-2-ones. J. Med. Chem. 35: 2095103 [PMID:1597859]

197. Sliskovic DR, Picard JA, Roark WH, Roth BD, Ferguson E, Krause BR, Newton RS, Sekerke C and Shaw MK. (1991) Inhibitors of cholesterol biosynthesis. 4. trans-6-[2-(substitutedquinolinyl)ethenyl/ethyl]tetrahydro-4-hydroxy-2 H-pyran-2-ones, a novel series of HMG-CoA reductase inhibitors. J. Med. Chem. 34: 367-73 [PMID:1992138]

198. Sliskovic DR, Roth BD, Wilson MW, Hoefle ML and Newton RS. (1990) Inhibitors of cholesterol biosynthesis. 2. 1,3,5-trisubstituted [2-(tetrahydro-4-hydroxy-2-oxopyran-6-yl)ethyl]pyrazoles. J. Med. Chem. 33: 31-8 [PMID:2296027]

199. Soltis DA, McMahon G, Caplan SL, Dudas DA, Chamberlin HA, Vattay A, Dottavio D, Rucker ML, Engstrom RG and Cornell-Kennon SA. (1995) Expression, purification, and characterization of the human squalene synthase: use of yeast and baculoviral systems. Arch. Biochem. Biophys. 316: 713-23 [PMID:7864626]

200. Song Y, Lin FY, Yin F, Hensler M, Rodrígues Poveda CA, Mukkamala D, Cao R, Wang H, Morita CT and González Pacanowska D et al.. (2009) Phosphonosulfonates are potent, selective inhibitors of dehydrosqualene synthase and staphyloxanthin biosynthesis in Staphylococcus aureus. J. Med. Chem. 52: 976-88 [PMID:19191557]

201. Song Y, Liu Cl, Lin FY, No JH, Hensler M, Liu YL, Jeng WY, Low J, Liu GY and Nizet Łt al.. (2009) Inhibition of staphyloxanthin virulence factor biosynthesis in Staphylococcus aureus: in vitro, in vivo, and crystallographic results. J. Med. Chem. 52: 3869-80 [PMID:19456099]

202. Stach D, Zheng YF, Perez AL, Oehlschlager AC, Abe I, Prestwich GD and Hartman PG. (1997) Synthesis and inhibition studies of sulfur-substituted squalene oxide analogues as mechanism-based inhibitors of 2,3-oxidosqualene-lanosterol cyclase. J. Med. Chem. 40: 201-9 [PMID:9003518]

203. Staedler D, Chapuis-Bernasconi C, Dehmlow H, Fischer H, Juillerat-Jeanneret L and Aebi JD. (2012) Cytotoxic effects of combination of oxidosqualene cyclase inhibitors with atorvastatin in human cancer cells. J. Med. Chem. 55: 4990-5002 [PMID:22533316]

204. Stokker GE, Alberts AW, Gilfillan JL, Huff JW and Smith RL. (1986) 3-Hydroxy-3-methylglutaryl-coenzyme A reductase inhibitors. 5. 6-(Fluoren-9-yl)- and 6-(fluoren-9-ylidenyl)-3,5-dihydroxyhexanoic acids and their lactone derivatives. J. Med. Chem. 29: 852-5 [PMID:3701793]

205. Stokker GE, Hoffman WF, Alberts AW, Cragoe EJ, Deana AA, Gilfillan JL, Huff JW, Novello FC, Prugh JD and Smith RL. (1985) 3-Hydroxy-3-methylglutaryl-coenzyme A reductase inhibitors. 1. Structural modification of 5-substituted 3,5-dihydroxypentanoic acids and their lactone derivatives. J. Med. Chem. 28: 347-58 [PMID:3973903]

206. Suzuki M, Iwasaki H, Fujikawa Y, Sakashita M, Kitahara M and Sakoda R. (2001) Synthesis and biological evaluations of condensed pyridine and condensed pyrimidine-based HMG-CoA reductase inhibitors.

Bioorg. Med. Chem. Lett. 11: 1285-8 [PMID:11392538]

207. Szabo CM, Matsumura Y, Fukura S, Martin MB, Sanders JM, Sengupta S, Cieslak JA, Loftus TC, Lea CR and Lee HJ et al.. (2002) Inhibition of geranylgeranyl diphosphate synthase by bisphosphonates and diphosphates: a potential route to new bone antiresorption and antiparasitic agents. J. Med. Chem. 45 : 2185-96 [PMID:12014956]

208. Tanaka RD, Schafer BL, Lee LY, Freudenberger JS and Mosley ST. (1990) Purification and regulation of mevalonate kinase from rat liver. J. Biol. Chem. 265: 2391-8 [PMID:2153681]

209. Tang M, Odejinmi SI, Allette YM, Vankayalapati H and Lai K. (2011) Identification of novel small molecule inhibitors of 4-diphosphocytidyl-2-C-methyl-D-erythritol (CDP-ME) kinase of Gram-negative bacteria. Bioorg. Med. Chem. 19: 5886-95 [PMID:21903402]

210. Thilagavathi R, Kumar R, Aparna V, Sobhia ME, Gopalakrishnan B and Chakraborti AK. (2005) Threedimensional quantitative structure (3-D QSAR) activity relationship studies on imidazolyl and N-pyrrolyl heptenoates as 3-hydroxy-3-methylglutaryl-CoA reductase (HMGR) inhibitors by comparative molecular 
similarity indices analysis (CoMSIA). Bioorg. Med. Chem. Lett. 15: 1027-32 [PMID:15686906]

211. Thoma R, Schulz-Gasch T, D'Arcy B, Benz J, Aebi J, Dehmlow H, Hennig M, Stihle M and Ruf A. (2004) Insight into steroid scaffold formation from the structure of human oxidosqualene cyclase. Nature 432: 11822 [PMID:15525992]

212. Thompson GN, Hsu BY, Pitt JJ, Treacy E and Stanley CA. (1997) Fasting hypoketotic coma in a child with deficiency of mitochondrial 3-hydroxy-3-methylglutaryl-CoA synthase. N. Engl. J. Med. 337: 1203-7 [PMID:9337379]

213. Thompson JF, Danley DE, Mazzalupo S, Milos PM, Lira ME and Harwood HJ. (1998) Truncation of human squalene synthase yields active, crystallizable protein. Arch. Biochem. Biophys. 350: 283-90 [PMID:9473303]

214. Thompson K, Dunford JE, Ebetino FH and Rogers MJ. (2002) Identification of a bisphosphonate that inhibits isopentenyl diphosphate isomerase and farnesyl diphosphate synthase. Biochem. Biophys. Res. Commun. 290: 869-73 [PMID:11785983]

215. Toth MJ and Huwyler L. (1996) Molecular cloning and expression of the cDNAs encoding human and yeast mevalonate pyrophosphate decarboxylase. J. Biol. Chem. 271: 7895-8 [PMID:8626466]

216. Toth MJ, Huwyler L and Park J. (1996) Purification of rat liver mevalonate pyrophosphate decarboxylase. Prep. Biochem. Biotechnol. 26: 47-51 [PMID:8744421]

217. van der Burgh R, Ter Haar NM, Boes ML and Frenkel J. (2013) Mevalonate kinase deficiency, a metabolic autoinflammatory disease. Clin. Immunol. 147: 197-206 [PMID:23110805]

218. Vlattas I, Dellureficio J, Ku E, Bohacek R and Zhang X.. (1996) Inhibition of mevalonate 5-pyrophosphate decarboxylase by a proline-containing transition state analog. Bioorg. Med. Chem. Lett. 6: 2091-2096

219. Voynova NE, Fu Z, Battaile KP, Herdendorf TJ, Kim JJ and Miziorko HM. (2008) Human mevalonate diphosphate decarboxylase: characterization, investigation of the mevalonate diphosphate binding site, and crystal structure. Arch. Biochem. Biophys. 480: 58-67 [PMID:18823933]

220. Voynova NE, Rios SE and Miziorko HM. (2004) Staphylococcus aureus mevalonate kinase: isolation and characterization of an enzyme of the isoprenoid biosynthetic pathway. J. Bacteriol. 186: 61-7 [PMID:14679225]

221. Wakazono A, Fukao T, Yamaguchi S, Hori T, Orii T, Lambert M, Mitchell GA, Lee GW and Hashimoto T. (1995) Molecular, biochemical, and clinical characterization of mitochondrial acetoacetyl-coenzyme A thiolase deficiency in two further patients. Hum. Mutat. 5: 34-42 [PMID:7728148]

222. Wang X, Wang H, Cao M, Li Z, Chen X, Patenia C, Gore A, Abboud EB, Al-Rajhi AA and Lewis RAet al. (2011) Whole-exome sequencing identifies ALMS1, IQCB1, CNGA3, and MYO7A mutations in patients with Leber congenital amaurosis. Hum. Mutat. 32: 1450-9 [PMID:21901789]

223. Waterham HR. (2002) Inherited disorders of cholesterol biosynthesis. Clin. Genet. 61: 393-403 [PMID:12121345]

224. Waterham HR. (2006) Defects of cholesterol biosynthesis.FEBS Lett. 580: 5442-9 [PMID:16876788]

225. Wattanasin S, Boettcher BR and Scallen T. (1997) N-Hydroxyglycine derivatives as novel inhibitors of squalene synthase. Bioorg. Med. Chem. Lett. 7: 3039-3044

226. Weingärtner O, Lütjohann D, Böhm M and Laufs U. (2010) Relationship between cholesterol synthesis and intestinal absorption is associated with cardiovascular risk. Atherosclerosis 210: 362-5 [PMID:20116793]

227. Wess G, Kramer W, Han XB, Bock K, Enhsen A, Glombik H, Baringhaus KH, Böger G, Urmann M and Hoffmann A. (1994) Synthesis and biological activity of bile acid-derived HMG-CoA reductase inhibitors. The role of 21-methyl in recognition of HMG-CoA reductase and the ileal bile acid transport system. $J$. Med. Chem. 37: 3240-6 [PMID:7932551]

228. Wiemer AJ, Tong H, Swanson KM and Hohl RJ. (2007) Digeranyl bisphosphonate inhibits geranylgeranyl pyrophosphate synthase. Biochem. Biophys. Res. Commun. 353: 921-5 [PMID:17208200]

229. Wiemer AJ, Yu JS, Lamb KM, Hohl RJ and Wiemer DF. (2008) Mono- and dialkyl isoprenoid bisphosphonates as geranylgeranyl diphosphate synthase inhibitors. Bioorg. Med. Chem. 16: 390-9 [PMID:17905588]

230. Wiemer AJ, Yu JS, Shull LW, Barney RJ, Wasko BM, Lamb KM, Hohl RJ and Wiemer DF. (2008) 
Pivaloyloxymethyl-modified isoprenoid bisphosphonates display enhanced inhibition of cellular geranylgeranylation. Bioorg. Med. Chem. 16: 3652-60 [PMID:18308574]

231. Wysocka-Kapcinska M, Lutyk-Nadolska J, Kiliszek M, Plochocka D, Maciag M, Leszczynska A, Rytka J and Burzynska B. (2009) Functional expression of human HMG-CoA reductase in Saccharomyces cerevisiae: a system to analyse normal and mutated versions of the enzyme in the context of statin treatment. J. Appl. Microbiol. 106: 895-902 [PMID:19187128]

232. Yasojima K, McGeer EG and McGeer PL. (2001) 3-hydroxy-3-methylglutaryl-coenzyme A reductase mRNA in Alzheimer and control brain. Neuroreport 12: 2935-8 [PMID:11588606]

233. Yoshida T, Asanuma M, Grossmann L, Fuse M, Shibata T, Yonekawa T, Tanaka T, Ueno K, Yasuda T and Saito Y et al.. (2006) Geranylgeranyl-pyrophosphate (GGPP) synthase is down-regulated during differentiation of osteoblastic cell line MC3T3-E1. FEBS Lett. 580: 5203-7 [PMID:16978613]

234. Young M, Chen H, Lalioti MD and Antonarakis SE. (1996) The human lanosterol synthase gene maps to chromosome 21q22.3. Hum. Genet. 97: 620-4 [PMID:8655142]

235. Young NL, Saudek CD, Crawford SA and Zuckerbrod SL. (1982) Recovery and activation of hydroxymethylglutaryl coenzyme A reductase from rat small intestine. J. Lipid Res. 23: 257-65 [PMID:7077140]

236. Yuan ZB, Han TQ, Jiang ZY, Fei J, Zhang Y, Qin J, Tian ZJ, Shang J, Jiang ZH and Cai X't al.. (2005) Expression profiling suggests a regulatory role of gallbladder in lipid homeostasis. World J. Gastroenterol. 11: 2109-16 [PMID:15810076]

237. Zhang C, Liu L, Xu H, Wei Z, Wang Y, Lin Y and Gong W. (2007) Crystal structures of human IPP isomerase: new insights into the catalytic mechanism. J. Mol. Biol. 366: 1437-46 [PMID:17137593]

238. Zhang SQ, Jiang T, Li M, Zhang X, Ren YQ, Wei SC, Sun LD, Cheng H, Li Y and Yin XVet al.. (2012) Exome sequencing identifies MVK mutations in disseminated superficial actinic porokeratosis. Nat. Genet. 44: 1156-60 [PMID:22983302]

239. Zhang Y, Cao R, Yin F, Hudock MP, Guo RT, Krysiak K, Mukherjee S, Gao YG, Robinson H and Song Y et al.. (2009) Lipophilic bisphosphonates as dual farnesyl/geranylgeranyl diphosphate synthase inhibitors: an X-ray and NMR investigation. J. Am. Chem. Soc. 131: 5153-62 [PMID:19309137]

240. Zhang Y, Hudock MP, Krysiak K, Cao R, Bergan K, Yin F, Leon A and Oldfield E. (2007) Activity of sulfonium bisphosphonates on tumor cell lines. J. Med. Chem. 50: 6067-79 [PMID:17963374]

241. Zhao S, Zhou W and Liu J. (2009) Synthesis and HMG-CoA reductase inhibition of 2-cyclopropyl-4thiophenyl-quinoline mevalonolactones. Bioorg. Med. Chem. 17: 7915-23 [PMID:19879766]

242. Zhao Y, Yu L, Gao J, Fu Q, Hua Y, Zhang H and Zhao S. (2000) cDNA cloning, chromosome mapping and expression characterization of human geranylgeranyl pyrophosphate synthase. Sci. China, C, Life Sci. 43: 613-22 [PMID:18726356]

243. Zheng W, Sun F, Bartlam M, Li X, Li R and Rao Z. (2007) The crystal structure of human isopentenyl diphosphate isomerase at $1.7 \mathrm{~A}$ resolution reveals its catalytic mechanism in isoprenoid biosynthesis. $J$. Mol. Biol. 366: 1447-58 [PMID:17250851] 